\title{
GEOPOLITIČKO PONAŠANJE SAVREMENE TURSKE
}

\begin{abstract}
A utor u tekstu sagledava geopolitičko ponašanje savremene Turske, u periodu 1991-2018. Uočava da u tom vremenu postoje četiri različita perioda turske spoljne i unutrašnje politike, tj. njenog geopolitičkog ponašanja. To su: panturkizam (tokom devedesetih godina 20. veka), evroazijsko približavanje (od 2003. do 2007, delimično do 2011), neoosmanizam (od 2011. do 2016), i najnoviji period ponovog evroazijsko približavanja (od 2016). Cilj rada je komparativna geopolitička analiza ova četiri geopolitička perioda savremene Turske, kako bi se dali adekvatni geopolitički odgovori zašto je trenutna pozicija Turske na spoljnom i unutrašnjem planu usmerena ka saradnji sa Rusijom i distanciranjem od Zapada. Posle uvoda, gde smo definisali istraživačko pitanje i teorijski pristup, prvi deo govori o panturkizmu, kao prvom periodu savremene geopolitike Turske. Drugi deo rada je analiza perioda avroazijskog približavanja. Treći i četvrti deo rada razmatra period neoosmanizma. Peti deo rada je i zaključni, a govori o ponovom nastupu evroazijskog približavanja Turske i njenog otklona od neoosmanizma. Osim komparativne analize različitih perioda u tekstu ćemo delimično razjasniti i unutrašnju komponentu geopolitičkog ponašanja savremene Turske.
\end{abstract}

Ključne reči: Turska, geopolitika, panturkizam, neoosmanizam, kemalizam, Evroazija, Rusija, SAD, spoljna politika, unutrašnja politika

Uvod

Svedoci smo da savremena Turska počinje da vodi novu geopolitiku u regionu

Bliskog istoka, u odnosima sa Rusijom, Iranom, kao i u odnosima sa Sjedinjenim Američkim Državama (SAD) i Severoatlantskim savezom (NATO). Mnogi istraživači postavljaju pitanje kakva je geopolitička orijentacija Turske? Pojedini autori smatraju da su u pitanju određene nesuglasice sa Vašingtonom i Briselom (NATO), ali da su one privremenog karaktera, da nesuglasice neće bitnije uticati na atlantističku orijentaciju Turske. Takve analize su posledica što je akademski i naučni diskurs u Srbiji, kao i u regionu, veoma siromašan sadržajnijim sagledavanjem geopolitike. Analize se odnose samo na neke spoljnopolitičke aspekte. Unutrašnji karakter geopolitike i geopolitički identitet se slabo istražuju. S tim u vezi, većina autora posmatraju tursku geopolitiku kroz geopolitički položaj Turske, kroz određene spoljnopolitičke poteze, ili ističu neoo- 
smanizam kao glavnu dimenziju turske geopolitike. ${ }^{1}$ Međutim, Turska je od 1991. godine promenila tri geopolitička usmerenja u svojoj spoljnoj politici, i nalazi se već u četvrtom periodu. Pitamo se zašto Turska menja svoje orijentacije? Da bismo odgovorili na to pitanje neophodno je dublje sagledavanje turskog identiteta, posebno njenog geopolitičkog identiteta.

Mi u ovom radu nemamo prostora za detaljniju analizu turskog geopolitičkog identiteta, ali ćemo se, ipak, kroz analizu četiri perioda savremene turske geopolitike dotaći i toga. Kroz tu analizu shvatićemo da Turska nema atlantistički identitet (identitet mora, talasokratije), već da je Tursku atlantizam upotrebljavao za svoje interese kontrole Evroazije, strateškog suzbijanja Rusije. Turska poseduje geopolitički identitet kopna (telurokratija), ali je u svojoj praktičnoj (geo)politici većinom bila u službi Zapada, atlantizma. To je u geopolitičkoj nauci označeno kao geopolitička podvojenost, raspolućenost. Nacija ima jedan identitet a pripada bloku koji baštini suprotan geopolitički identitet. ${ }^{2}$

Naše istraživačko pitanje glasi - da li je savremena Republika Turska ima konstantno geopolitičko ponašanje ili je u periodu 1991-2018. ona ispoljavala različite geopolitike? Uočavamo da Turska nije imala geopolitičku konstantu, i pitamo se koji su uzroci toga? Isto tako, kako je uticala unutrašnja dimenzija geopolitike, tj. kako je turski geopolitički identitet uticao na geopolitičko ponašanje? Da li je geopolitička raspolućenost Turske uslovila da ona ima različito geopolitičko ponašanje?

Prema tome, u ovom radu mi analiziramo jedan oblik delovanja političkog aktera. U ovom slučaju u pitanju je političko delovanje (ponašanje) turske države. Tražimo uzročno-posledičnu vezu između unutrašnje dimenzije turske politike, njenog identiteta i turskog spoljnopolitičkog delovanja (praktične geopolitike, tj. njene spoljne geopolitičke prakse). Isto tako, u definisanju strukture argumentacije u radu primenjujemo strukturalni argument. Naime, označava se unutrašnji aspekt političkog fenomena i, posebno, hipoteza koja nastoji da objasni da različito geopolitičko ponašanje Turske u poslednjih trideset godina ima svoje unutrašnje (strukturne) uzroke, kao i spoljašnje uzroke pripadanja Turske atlantizmu.

\section{Period panturkizma}

Prvi period počinje odmah nakon nestanka Sovjetskog Saveza. Turska, članica Severoatlantskog saveza (NATO), višedecenijski američki oslonac na južnim granicama Sovjetskog Saveza, i u Crnom moru, u geostrateškom ponašanju Sjedinjenih Američkih Država (SAD) dobija novu ulogu. Ta uloga je usmerena na suzbijanje ruske moći u regionu Kavkaza i u Srednjoj Aziji. Zbog toga Turska, u američkoj geopolitici, dobija status

\footnotetext{
${ }^{1}$ Videti analizu geopolitičkoj položaja Turske u: Momčilo Sakan, „Geopolitika Republike Turske“, Vojno delo, 1/2015, Beograd, str. 37-57.

${ }^{2}$ O različitim geopolitičkim identitetima, kao i o geopolitičkoj raspolućenosti videti u: Perišić Srđan, „Srbija i geopolitika: od identiteta ka praktičnoj geopolitici i strategiji“, Zbornik radova sa Naučnog skupa „Srbija i strategijska raskršća - ISIKS 2016“, Institut za strategijska istraživanja MO R.Srbije, Škola nacionalne odbrane Univerzitet odbrane, Beograd, 2016.
} 
"geopolitičkog stožera“. To jasno objašnjava u svojim radovima vodeći američki teoretičar geopolitike Zbignjev Bžežinski (Zbigniew Brzeziński). ${ }^{3}$

Naime, tokom 90-ih godina 20. veka, Vašington, preko obaveštajnih službi, Turskoj nameće projekat širenja uticaja na bivše sovjetske republike, samostalne države Centralne Azije (Kazahstan, Uzbekistan, Turmenistan i Kirgistan), kao i na turanske narode u samoj Rusiji, oko Volge i na Kavkazu, sve do Jakutije. Turskoj se sugeriše da iskoristi svoje etničko poreklo i odvoji Centralnu Aziju od viševekovne veze sa Rusijom. Tako nastaje projekat Velike Turske, poznat i kao panturkizam. Mnogi smatraju da su Turci osmislili taj projekat, zbog svojih nacionalističkih težnji. Međutim, to je netačno. Panturkizam je bio ideja sledbenika atlantizma, zapadnjaka, predstavnika američkog strateškog geopolitičkog planiranja za Tursku. ${ }^{4}$

Panturkizam je, dakle, projekat američke geostrategije onemogućavanja Rusije na prostoru Evroazije, odvajanjem država Centralne Azije od saradnje sa Rusijom. Koristi se jezička bliskost Turske sa turanskim narodima Azije. Tako je već 1993. formirana Međunarodna organizacija turske kulture (TÜRKSOY, rus. TюrKSOЙ) čije su članice: Azerbejdžan, Kazahstan, Kirgizija, Turkmenija, Uzbekistan i Turska. Do 2015. godine članice ove organizacije su bile i ruske republike Baškortostan, Tuva, Altaj, Hakasija i Jakutija (Saha). ${ }^{5}$ No, Turska je najviše delovala na jačanju privrednih i vojnih veza. Tako je ponudila centralno-azijskim državama da školuju svoje oficire u Turskoj. Kreditirala je ove države (1996. godine je dala Kazahstanu kredit od 300 mlrd američkih dolara, povrh investicija od oko 1.2 mlrd američkih dolara). ${ }^{6}$

Međutim, svi ovi pokušaji odvajanja Centralne Azije od Rusije su doživeli fijasko. Pokušaji Turske da realizuje američki projekat panturkizma, kao geopolitički projekat vezivanja Centralne Azije širenjem turanskog obrazovanja i preorijentacije na Tursku Kazahstana, Uzbekistana, Turkmenistana i Kirgistana su propali. Zašto?

Prvo, veze naroda Centralne Azije sa ruskom kulturom i državom su viševekovne i teško ih je bilo uništiti. Nacionalna izgradnja tih naroda je upravo i ostvarena u zajednici sa Rusijom. Narodi centralne Azije su sa Rusijom živeli mirno, prihvatajući mnoge ruske kulturne obrasce, tako da je nemoguće bilo Turskoj da zameni Rusiju. Drugo, ni sami Turci, bez obzira koliko bili podsticani od SAD, nisu bili potpuno posvećeni tom cilju. Aleksandar Dugin navodi da se Turci „nisu realno preterano uneli u to“. Oni su podržavali ta projekat, ali dosta pasivno. ${ }^{7}$ Naime, Dugin dobro primećuje da je „pravi realni interes Turske očuvanje njenih državnih granica, koje su same po sebi problematične zbog moćnog kurdskog faktora“, 8 pa je panturkizam izgledao nešto kao daleka spoljna misija, koja je i drugorazredna u uslovima unutrašnjih protivrečnosti.

\footnotetext{
${ }^{3}$ Zbignjev Bžežinski, Velika šahovska tabla, CID Podgorica, 1999, str. 48.

${ }^{4}$ Александар Дугин, „Неоосманская иллюзия Турции“, Нешсланд, Москва, 25.01.2013, https://newsland.com/user/4297700690/content/aleksandr-dugin-neoosmanskaia-illiuzila-turtsii/4438003 (pristupljeno: jan. 2018).

${ }^{5}$ Елена Мейгун, „Власти тюркских регионов выбирают между Россией и Турцией“, Национальный акцент, Москва, 27.12.2015, http://nazaccent.ru/content/18885-svoj-ili-tyurksoj.html (pristupljeno: mart 2018).

${ }^{6}$ Zbignjev Bžežinski, op.cit, str. 139.

${ }^{7}$ Aleksandar Dugin, „Tursku sa neoosmanizmom čekaju haos, neredi i raspad države“, Nova srpska politička misao, Beograd, februar 2013, http://www.nspm.rs/hronika/aleksandar-dugin-tursku-sa-neo-osmanizmomcekaju-haos-neredi-i-raspad-drzave.html?alphabet=l (pristupljeno: april 2018).

${ }^{8}$ Aleksandar Dugin, „Tursku sa neoosmanizmom čekaju haos, neredi i raspad države“, op.cit.
} 


\section{Period evroazijskog zbližavanja}

Drugi period počinje sa dolaskom Partije pravde i razvoja (AKP) na vlast i Redžepa Erdogana (Recep Erdoğan) na poziciju premijera Turske. Taj period jasno traje od 2003. do 2007. godine, i delimično do 2011. Tada tursko vođstvo postepeno počinje da razvija - evroazijski projekat. Evroazijski zaokret Turske je počeo kada se u Ankari shvatilo da je suprotstavljanje Rusiji, kroz strategiju panturkizma, uzaludno. Naime, ponovo se, kao za vreme Kemala Ataturka, iskristalisala ideja revizije odnosa prema Rusiji, koja ne preti turskim interesima. ${ }^{9}$ Turskoj nametnuti američki projekat panturkizma, usmeren na suzbijanje moći Rusije na prostoru Centralne Azije i Kavkaza, zamenjen je 2000-tih godina od strane turskog vođstva evroazijskim projektom postepene saradnje sa Rusijom.

Sve je započelo sa razvojem turske privrede. Ekonomski razvoj je bio posebno izražen u prvom premijerskom mandatu Erdogana. Bruto društveni proizvod (BDP) po glavi stanovnika povećao se sa 3.910 na 10.000 američkih dolara, sa ekonomskim rastom od $8,9 \%$ godišnje. Time je Turska bila iznad evropskog proseka i svake pojedine članice. ${ }^{10}$ Tada je i došlo do ekonomskog zbližavanja Rusije i Turske. Nekoliko puta je porasla trgovinska razmena. Tako je 2010. godine Rusija postala drugi spoljnotrgovinski partner Turske. Ruski turisti su postali neodvojivi deo turske ekonomije (2010. godine Tursku je posetilo 3.1 milion ruskih turista). ${ }^{11}$ Energetska saradnja se odvijala jačanjem kapaciteta gasovoda Plave reke, koji je počeo sa radom 2003. godine. Njime je Rusija prvi put u svojoj energetskoj politici zaobišla jednu državu koja je bila pod kontrolom Vašingtona Gruziju. Dakle, uz pomoć Turske - što je do tada bilo nezamislivo. ${ }^{12}$

Dakle, sve rusko-turske aktivnosti su se ispoljavale u nekom političkom evroazijstvu. Turska je zauzela kurs saradnje i zbližavanja sa Rusijom i donekle sa Iranom. Jednostavno, Turska se postepeno udaljavala od SAD. To je pojačano kada se shvatila uloga SAD u Iraku, posle invazije na tu zemlju. Naime, Vašington je aktivirao kurdski problem i

\footnotetext{
${ }^{9}$ Marta 1921. godine Vlada Sovjetske Rusije i Velika nacionalna skupština Turske (pod kontrolom Mustafe Kemala - Ataturka) su, dakle, pre proglašenja Republike Turske (1923.) uspostavili međusobne diplomatske odnose. Tada se Sovjetska Rusija svrstala na stranu turskih nacionalista - kemalista u tursko-turskim sukobima, i u tursko-grčkom ratu. Sovjetska Rusija je smatrala da je vojna intervencija Kraljevine Grčke na prostoru Male Azije (grad Smirna), potpomognuta zapadnim državama, čin imperijalizma, a ne nacionalno oslobođenje Grka. Potpisan je Moskovski dogovor kojim je Sovjetska Rusija postala prva država koja je priznala kemalistički pokret i njegovu vladu. Zapadne države su u to vreme priznavale vladu sultana Mehmeda VI. Za vreme života Kemala Ataturka (umro 1938) Republika Turska i Sovjetski Savez su imali dobre odnose, posebno ekonomske i vojne. Moskva je Ankari obezbeđivala povoljne privredne kredite. 1933. godine potpisan je Sporazum o prijateljstvu i saradnji. Zanimljivo je da na velikom spomeniku Ataturkovim revolucionarima na Trgu Taksim u Instambulu, levo od isklesanog lika Ataturka se nalaze likovi ruskih revolucionara, maršala Klimenta Vorošilova i Mihaila Frunzea. - Videti: Варткез Арцруни, „К истории советско-турецких отношений и дружбы большевиков с Ататюрком“, Ноевковчег, №10-11, июнь 2015, Москва. (стр. 262-273). Павел Шлыков, „Анкара смеется последней - Как Советская Россия помогла становлению независимой Турции“, Лента, Москва, април 2016.

${ }^{10}$ Dževad Galijašević, „Neoosmanizam: Turska između juče i sutra“, Politea, br.2/2011, Fakultet političkih nauka, Banjaluka, str. 131.

${ }^{11}$ Вести Турции Босфор: „Турция и Россия договорились о безвизовом режиме“, 17.3.2011, http://www.vestiturkey.com/turci-i-rossi-dogovorilis-o-bezvizovom-rezime-707h.htm (pristupljeno: maj 2018).

${ }^{12}$ Srđan Perišić, Nova geopolitika Rusije, Medija centar Odbrana, Beograd, 2015, str. 171.
} 
time Tursku stavio u nezgodan položaj. ${ }^{13}$ Unutrašnje protivrečnosti Turske su, američkim otvaranjem kurdskog pitanja u regionu, ponovo došle do izražaja. Politika SAD na Bliskom Istoku počinje da predstavlja pretnju interesima Turske. Zbog toga Turska se sve više oslanja na Rusiju. ${ }^{14}$

\section{Period neoosmanizma - obračun sa evroazijskom orijentacijom}

Treći period geopolitike Turske je period neoosmanizma i predstavlja ponovo negaciju i odbacivanje evroazijskog usmerenja Turske i saradnje sa Rusijom, Iranom, Sirijom. Projekat neoosmanizma je podržan od strane Vašingtona, jer su SAD u njemu našle mogućnost zaustavljanja Turske da se odvoji od Zapada, NATO-a i SAD. Taj period postepeno počinje da zaživljava posle 2007. godine, a vrhunac dostiže u 2012. hapšenjem gotovo celokupnog vojnog vrha, mnogih političara, pisaca, novinara, advokata. Period dominacije neoosmanizma se može pratiti sve do 2016. godine i obnavljanja odnosa sa Rusijom.

Neoosmanski projekat se karakteriše:

1) represijom prema svima koji su bili za preispitivanje turskog oslanjanja na Vašington - slučaj „Ergenekon“;

2) delovanjem pokreta Hizmet imama Fetulaha Gilena (Fethullah Gülen);

3) neoosmanskom strategijom izraženom u programskim radovima univerzitetskog profesora, ministra, i jedno vreme premijera, Ahmeta Davutoglua (Ahmet Davutoğlu);

4) geostrategijskim oslanjanjem na SAD i NATO i naglim zahlađivanjem odnosa sa Rusijom.

5) podrškom Saudijskoj Arabiji, islamskim salafističkim, vehabističkim centrima, i terorizmu.

Vašington je shvatio da se Turska udaljava od SAD, pogotovo posle otvaranja kurdskog pitanja. Zbog toga američke tajne službe u saradnji sa pokretom Hizmet otvaraju slučaj „Ergenekon“. Tim slučajem su optužili vojno rukovodstvo Turske za zaveru navodno sračunatu na pokušaj državnog prevrata. Naime, iskorištena je istorijska činjenica da je turski vojni vrh više puta izvodio državne udare. Odnosno, iskorištena je činjenica da vojni vrh uspostavljao kontrolu nad zemljom, izvodio državni udar - kada je politika izlazila iz okvira kemalizma. To je bilo 1960, 1971, 1980, i 1997. godine. Jednostavno, bilo je potrebno skloniti postojeće vojno rukovodstvo Turske, koje je sve više naginjalo ka saradnji sa Rusijom, Iranom, ka evroazijskoj politici i udaljavanju od SAD - optužbom da je pripremalo novi vojni udar.

\footnotetext{
${ }^{13}$ O kurdskom pitanju videti: Kuzmanović B, Kovač M, „Implikacije kurdskog nacionalnog pitanja na situaciju u Turskoj“, Vojno delo, 2/2018, Beograd, str. 113 - 134

${ }^{14}$ Turska se oštro protivila američkoj agresiji na Irak. Nije dozvolila da se napad izvodi sa njene teritorije. Međutim, američka vojska je uspostavila saradnju sa kurdskim vojnim formacijama (pešmerzi) na severu Iraka uz granicu sa Turskom. Kurdske snage su brojale oko 70000 boraca. - Videti: Isaac J. Peltier, Surrogate Warfare: The Role of U.S. Army Special Forces, School of Advanced Military Studies United States Army Command and General Staff College Fort Leavenworth, Kansas, 2004/2005, p. 24-30
} 
Dakle, otvaranjem slučaja „Ergenekon“, 2007. godine, počinje obračun sa evroazijskim projektom, koji je u to vreme bio u rukama dela kulturne, vojne i ekonomske elite Turske i postepeno počinje neoosmanski period. Prvo je počeo obračun sa medijskom i kulturnom elitom Turske (hapšenjem pisaca, novinara, političara), da bi posle 2011. krenuo i obračun sa najvišim vrhom u turskoj armiji. Načelnik Generalštaba Turske armije, Ilker Bašbuh (Illker Başbuğ) je osuđen na doživotni zatvor, sa još 16 generala, oficira, novinara, advokata. Ukupno je osuđeno 330 ljudi. $^{15}$

Naime, slučaj „Ergenekon“ je trebalo da bude definitivna pobeda turskih islamista. Međutim, britanski ekspert Garet Dženkins (Gareth Jenkins), sa Univerziteta Džons Hopkins (Johns Hopkins University), analizirajući ovaj slučaj je došao do činjenica da iza celog procesa nije stajao Tajip Erdogan, već pokret Hizmet, turskog imama Fetulaha Gilena. Gilenisti su se decenijama, a posebno koristeći se saradnjom sa Erdoganovom Partijom pravde i razvoja, ubacivali u sve pore društva i države. Stvarali su paralelnu vlast preko postojećih institucija sudske i izvršne vlasti. Posebno su prisutni bili u medijskim kućama, univerzitetima, raznim privrednim korporacijama, sudskoj vlasti, policiji i armiji. Vođa pokreta Gilen živi u SAD, a sam pokret je prisutan u Evropi, Aziji i SAD. ${ }^{16}$

Slučaj „Ergenekon“, a posebno hapšenje 2012. godine generala Bašbuha, kao i mnoštva turskih generala, kako ističe Garet Dženkins, nastojalo se pokazati da u Turskoj niko više nije nedodirljiv. Isto tako, hapšenja su pokazala da Gulenov pokret ima ogromnu moć, veću od same vlasti Erdogana. Ovaj britanski naučnik i istraživač, u analizi slučaja „Ergenekon“, još 2012. godine je zaključio da u današnjoj Turskoj nije vojska, već Gulenov pokret Hizmet taj koji je nosilac sukoba. ${ }^{17}$

Slučaj „Ergenekon“ je usmeren na likvidaciji evroazijske orijentacije i politike Turske. Njega je preko moćnog pokreta Hizmet, inicirao Vašington - da bi se zaustavilo tursko evroazijsko zbližavanje sa Rusijom. To se može zaključiti i na osnovu hapšenja turskog sekularnog političara, kemaliste Dogua Perinčeka (Doğu Perinçek), koji je imao saradnju sa ruskim političkim partijama. On je delovao u pravcu evroazijskog usmerenja Turske što je bilo uočeno od strane američkih službi. Gilenisti su ga lažno optužili za zaveru i pripadnost „Ergenekonu“ i osuđen je drakonski na 117 godina zatvora - najvišu kaznu od svih optuženih. Turski politikolog, lider Radničke partije Turske i jedan od vodećih turskih sekularista, Mehmet Perinček (Mehmet Perinçek) navodi da su „Ergenekon“ pokrenule SAD, jer su bile zabrinute činjenicom da je 2009. u delu vojne elite pokrenuto pitanje povlačenja iz NATO-a. On kaže: „Slučaj Ergenekon je brižljivo planirana operacija Vašingtona protiv turskih patriota, turskih patriota koji su usmereni antiamerički". ${ }^{18}$

\footnotetext{
${ }^{15}$ Suđenje navodnim članovima organizacije „Ergenekon“ praćeno je raznim skandalima, nelegalnim prisluškivanjem, amaterski podmetnutim dokazima. „Kao najšokatniji primer jeste da je 330 aktivnih i penzionisanih pripadnika oružanih snaga Turske osuđeno na zatvorske kazne zbog planiranja državnog udara 2003. godine - iako se optužba zasnivala na CD-u za koji je ustanovljeno da je sadržao verziju paketa Majkrosoft Ofis iz 2007." Christopher de Bellaigue, „Turkey Goes Out of Control“, The New York Review of Books, 3. April 2014.

${ }^{16}$ O pokretu Hizmet videti u: Miša Đurković, "Fetulah Gjulen i džemat Hizmet", Polja geopolitike - zbornik radova (prir. Ljubiša Despotović, Veselin Konatar), Kultura - polis i Fakultet za evropske i pravno političke studije, 2016.

${ }^{17}$ Gareth H. Jenkins, "The Changing Object of Fear: The Arrest of Ilker Basbug" (9 January 2012). https://www.turkeyanalyst.org/publications/turkey-analyst-articles/item/290-the-changing-objects-of-fear-thearrest-of-ilker-basbug.html

18 Василий Папава, „Интервью с М.Перинчеком“, Ежемесячный общественно-политический журнал «Кавказский Акцент». № 12 за декабрь 2010.
} 
Upravo korištenjem pokreta Hizmet Amerikanci su povratili uticaj na Tursku i na Erdogana. Sa slučajem „Ergenekon“, i likvidacijom evroazijskog uticaja među samom elitom Turske, počinje period Turske geopolitike poznat kao neoosmanski projekat.

Neoosmanizam je u teorijskom smislu postavio Ahmet Davutoglu. On se oslanjao i na idejne smernice pokreta Hizmet. Davutogluova politika neoosmanizma je predstavljena u knjizi Strategija dubine: međunarodni položaj Turske. ${ }^{19}$ Knjiga jasno povezuje geopolitičke $i$ islamske ideje u jednu celinu. Ta celina je da Turska ima dubinu svojih nacionalnih interesa na prostoru Azije, Evrope, Severne Afrike koji su povezani sa svojom islamskom i osmanskom tradicijom.

$\mathrm{U}$ ideološkom smislu neoosmanizam je postepena reislamizacija društva. $\mathrm{S}$ tim u vezi, podrazumeva razgradnju temeljenih osnova sekularnosti i Ataturkovog nasleđa. Neoosmanizam ima plodno tlo, jer kemalistički sekularizam nije zahvatio sve pore društva, već ima samo delimičnu podršku u turskom društvu. Ideje sekularnosti, koje je postavio Kemal Ataturk, su prihvaćene u urbanim delovima Turske, kao i u većem delu same elite, ali široki delovi turske teritorije su ruralnog karaktera, udaljeni od velikih gradova Istambula, Ankare i priobalja Egejskog mora, i u njima narod Turske živi životom islamskog čoveka. Tanasković to jasno naglašava u knjizi Neoosmanizam: povratak Turske na Balkan, i navodi da je islam toliko prisutan da on nikada nije izgubio status individualnog i kolektivnog orijentira u životu većine Turaka. ${ }^{20}$

U geostrateškom smislu neoosmanizam podrazumeva povezivanje geopolitičkih, geoekonomskih, geokulturnih ideja i praksi u jedinstvenu celinu sa ciljem postizanja moći Turske, za jačanje njene međunarodne uloge i položaja. To znači i oslanjanje na države sa islamističkim režimima (Saudijska Arabija, Katar...), i oslanjanje i podrška muslimanima Balkana (Albanci, Bošnjaci) i podrška muslimanima Kavkaza i Srednje Azije.

Takođe, pod uticajem Gilenovog islamističkog pokreta, koji se inflitirao u sve pore turskog društva i vlasti, i naravno pod uticajem glavnog stratega Ahmeta Davutoglua - neoosmanizam je značio potpunu saradnju sa SAD. To je ključni elemenat neoosmanističkog projekta koji mnogi istraživači ne primećuju.

Prema tome, neoosmanski projekat Turske u svom geostrateškom smislu se ogleda u zbližavanju sa proameričkim arapskim režimima, pre svega u Saudijskoj Arabiji i Kataru. Neoosmanizmom Turska je čvrsto usmerena protiv Sirije u periodu 2012-2016. Isto tako, u tome periodu, neoosmanizmom Turska naglo zahlađuje odnose sa Iranom i Rusijom.

Kada ne bi bilo ovog atlantističkog elementa u neoosmanizmu, tj. oslanjanja na SAD i njihovu geopolitiku, neoosmanizam bi mogao biti kompatibilan sa evroazijskim usmerenjem. Međutim, upravo prihvatanje američke geopolitike u regionu, usmerene na gušenje ruske moći i uticaja Irana, neoosmanizam je potpuno na antievroazijskim i antiruskim pozicijama.

No, bez obzira na povezivanje neoosmanističke strategije sa atlantizmom, dakle na oslanjanje Turske na SAD, ipak - Vašington nije verovao Erdoganu. U sadejstvu sa Gilenovim pokretom Hizmet, Vašington je procenio da je turska armija u periodu 2011-2013. u velikoj meri očišćena od protivnika SAD, ali da treba sa vlasti smeniti i samog Erdogana. Pokrenute su demonstracije 2013. godine na Trgu Taksim, koje je Erdogan uspeo suzbiti. Definitivno je bilo jasno da je Erdogan nepredvidiv posle sporazuma sa Rusijom u decembru 2014. o izgradnji gasovoda Turski tok. Tako, krajem 2014. godine Gilenisti,

\footnotetext{
${ }^{19}$ Ahmet Davutoglu, Strategija dubine: međunarodni položaj Turske, Službeni glasnik, Beograd, 2014.

${ }^{20}$ Darko Tanasković, Neoosmanizam: povratak Turske na Balkan, JP Službeni glasnik, 2010, Beograd.
} 
infiltrirani u sudove, tužilaštvo i policiju pokreću udar na mnoge saradnike Erdogana i Partije pravde i razvoja, optužujući in za korupciju. Bez obzira što su mnogi državni službenici i političari stvarno bili u vezi sa korupcijom, udar Gilenista, podržan Vašingtonom, je bio pre svega usmeren protiv Erdogana. Gilenisti su bili posebno kivni na Erdogana jer je nešto ranije, tokom 2014. godine, oslobodio sve osuđene u slučaju „Ergenekon“. Naime, vrhovni sudovi Turske su zaključili da je „Ergenekon“ izmišljen slučaj bez dokaza. Među oslobođenim su bili i političari koji su se zalagali za saradnju sa Rusijom, kao i svi generali, među njima i bivši načelnik generalštaba Bašbuh. ${ }^{2}$

Erdoganova vlada krajem 2014. godine se okreće protiv gilenista. Međutim, Gilenisti su u svim porama države, u svakoj instituciji. Praktično predstavljaju paralelnu državu. Uporedo, neoosmanske ambicije Turske i njena otvorena podrška svim ekstremnim i terorističkim organizacijama u Siriji i Iraku, te otvoreno zalaganje za podelom Sirije i rušenje legalnih sekularnih vlasti, dovele su Tursku u tragični politički bezizlaz. Njena unutrašnja kohezija i stabilnost su 2014-2016. bile pod znakom pitanja. Posebno je to došlo do izražaja posle prekida odnosa sa Rusijom, izazvan obaranjem ruskog borbenog aviona u novembru 2015. godine - za koji se kasnije utvrdilo da je oboren pod uticajem Gilenista. Tursko vođstvo se praktično našlo u ćorsokaku jer je još jednom krenulo po atlantskom scenariju. Približilo se Americi, a udaljilo od Rusije i Teherana, od evroazijskog bloka. Aktivno se u uplelo u antisirijski sukob, podržavajući, zajedno sa Saudijcima, islamske ekstremiste.

\section{Koji su rezultati neoosmanizma?}

Neoosmanska geopolitika - posebno u njenom geostrateškom pogledu, je iluzija. Ideja o Velikoj neoosmanskoj Turskoj nalik Osmanskoj imperiji u savremenom uslovima, ni pod kakvim uslovima se ne može uspostaviti. Insistirajući na savezu sa Saudijskom Arabijom, Katarom i radikalnim vehabističkim centrima, tj. sa ekstremnim islamistima i teroristima, Turska je stigla do građanskog rata. 2016. godine je pretio rat između gilenista, nacionalista, kemalista i republikanaca. To bi izazvalo i raspad Turske, jer bi se u građanski rat umešali i Kurdi. To je uočila grupa političara iz Partije pravde i razvoja (AKP), a i sam Erdogan, posle prekida odnosa sa Rusijom u novembru 2015.

Erdogan je pokušao promenu Ustava Republike Turske i jačanje uloge predsednika. To nije uspeo zbog unutrašnjeg otpora i opstrukcija koje je predvodio premijer Ahmed Davutoglu. I Erdogan se odlučio na potpunu promenu spoljne politike Turske. Pre svega prema Rusiji.

Naravno, nije bilo odmah jasno, nakon sukoba Turske sa Rusijom, šta se dešava u Turskoj, ko ima kakve pozicije u vladajućoj stranci AKP, kakva je uloga vojske, šta rade spoljni politički faktori i kakav je odnos snaga. Nije se znalo ko je u Turskoj kolovođa antievroazijskih integracija i dobrih odnosa sa Rusijom?

Erdogan je smenio Davutoglua (prisilio ga na ostavku u maju 2016.). Prethodno je rehabilitovao generale i oficire iz slučaja Ergenekon koji su bili za saradnju sa Rusijom. Konačno, obnavlja odnose sa Rusijom 28. juna 2016. godine - uz lično izvinjenje Putinu. To je bio glavni razlog da se krene na Erdogana.

\footnotetext{
${ }^{21}$ Hurriyet Daily News: "Former army chief's jailing a rights violation: Top Turkish court". Hürriyet Daily News. 6 March 2014.
} 
Dakle, nije se smelo dozvoliti da Turska ponovo započne evroazijsku geopolitiku i saradnju sa Rusijom. U trenutku kada Sjedinjene Američke Države uz pomoć NATO instaliraju raketne štitove po Evropi, gomilaju vojsku i ratnu tehniku u baltičke zemlje, Poljsku, Rumuniju, Bugarsku, na granicama Rusije - obnavljanje odnosa Erdogana sa Moskvom postaje smetnja atlantističkim planovima obuzdavanja Rusije. To je glavni uzrok pokušaja vojnog puča 15. jula 2016. Iza pokušaja državnog udara Erdogan od samog početka veoma argumentovano tvrdi da stoje američke tajne službe, pokret Hizmet - pristalice Gilena u turskoj armiji. Zanimljivo je da vodeći političari u zemljama Evropske unije, posebno u početku izvođenja državnog udara, nisu osudili državni udar. Isto tako, to nisu uradili ni posle propasti državnog udara.

Erdogan je smenom Davutoglua u maju 2016. potpuno promenio rukovodeći sastav bezbednosnih službi, koji su odmah stupili u razmenu informacija sa Rusijom. Rezultat toga se pokazao na sam dan državnog udara. Naime, „šef ruske obaveštajne službe FSB Aleksandar Bortnjikov 15. jula poziva šefa nacionalne bezbednosne organizacije (MIT) Hakana Fidana, koji je, kao Erdoganov čovek od poverenja, krajem maja preuzeo funkciju“. ${ }^{22}$

Propali puč je pokazao promenu među turskom elitom. Ranije se turska elita delila na tri grupe: kemalisti, Gilenovi sledbenici i Erdoganovi umereni islamisti. Nakon ostavke Davutoglua i promene geopolitičkog kursa u pravcu približavanja Rusiji - spoljna politika Erdogana je postala bliža kemalistima. Činjenica da najveći deo vojske i generalštab nisu podržali pobunu je dokaz jednog novog saveza između Erdogana i kemalista. Gilenisti su pokušali da pridobiju sekulariste, ali geopolitika se pokazala kao važnija u biranju strane. ${ }^{23}$ Naime, evroazijski kurs je jedini način da se Turska sačuva u okvirima svojih granica. Dakle, od obnavljanja odnosa sa Rusijom u leto 2016. godine, Turska se ponovo nalazi na evroazijskom kursu. Tako da četvrti period Turske geopolitike upravo posmatramo.

Osnovne karakteristike trenutnog, evroazijskog usmerenja geopolitike Turske su:

1) Jaka saradnja sa Rusijom na ekonomskom, energetskom, političkom i vojnom planu;

2) Saradnja sa Rusijom i Iranom u Siriji, preko Astanskog formata, u vezi završetka rata (formiranje demilitarizovanih zona - zona deeskalacije u Siriji); ${ }^{24}$

3) Distanciranje od Evropske unije i geopolitičkih inicijativa Zapada;

4) Uravnoteženija politika Turske na Balkanu (dobri odnosi sa Srbijom), koja je rezultirala i umerenom politikom u Bosni i Hercegovini i po pitanju Kosova. ${ }^{25}$

\footnotetext{
${ }^{22}$ Državnim udarom je komandovao general Mehmet Dišli, brat bivšeg potpredsednika Erdoganove Partije pravde i razvoja. U pokušaju udara poginulo je 270-350 ljudi, od čega 180 civila, a odmah su usledila hapšenja više od 6.000 osoba, od čega najmanje 2.839 vojnika. - Videti: Boško Jakšić, „Nepoznati detalji neuspešnog državnog udara u Turskoj - Kako je poziv iz Moskve spasao Erdogana“, Politika, 20.09.2016, http://www.politika.rs/scc/clanak/363954/Kako-je-poziv-iz-Moskve-spasao-Erdogana (pristupljeno: 21.9.2018).

${ }^{23}$ Sudije i tužioci koji su učestvovali u suđenjima uslučaju „Ergenekona“ su posle propasti puča 15. jula, uglavnom pohapšeni ili su pobegli iz zemlje. Među onima koji su napustili zemlju je Džihan Kansiz, javni tužilac koji je lažno optužio generala Bašbuha i naredio njegovo hapšenje. Hasan Ozese, sudija koji je osudio generala Bašbuha na doživotnu robiju, uhapšen je jula 2016. - Daily Sabah, April 2016, High-profile Gülen Movement-linked suspects remain fugitives; http://www.dailysabah.com/investigations/2016/04/23/high-profilegulen-movement-linked-suspects-remain-fugitives; NTV, 20 July 2016, Ergenekon davası hakimi darbe soruşturmasında tutuklandı

${ }^{24}$ Astanski pregovori su počeli 2017. godine i te godine su imali šest rundi razgovora. Nosilac Astanskog formata su Rusija, Sirija i Iran i sirijska opozicija (bez terorističkih organizacija Islamske države i Al Kaide).
} 


\section{Zaključak}

Komparacijom sva četiri perioda geopolitičkog ponašanja savremene Turske, u periodu 1991 - 2018, uočavamo da su periodi različiti i da su uzrokovani dvojako. Prvo, Turska kao članica NATO sastavni je deo praktične geopolitike atlantizma (talasokratije). To je poznato. Međutim, manje je poznato da u Turskoj postoje političke ideje i težnje da se ona definiše kao evroazijski identitet (telurokratija) koji će imati saradnju sa Rusijom i drugim evroazijskim zemljama. Još manje je poznato da su takve ideje prodrle u samu armiju. Direktna posledica toga je i obračun sa komandnim kadrom turske armije koji je prihvatao izgradnju Turske u tom pravcu, a što bi na spoljnom planu značilo postepeno napuštanje atlantskog bloka. Obračun je izvršen u periodu 2011-2014. preko iskonstruisanog slučaja „Ergenekon“. Glavni nosilac tog obračuna je bila geopolitika neoosmanizma, neposredni izvršioci su bili pristalice Fetulaha Gilena u samoj državnoj vlasti i u armiji (paralelna država) i naravno jedan deo političke elite okupljene oko Davutoglua i Erdogana. Spoljni faktor tadašnjeg obračuna sa evroazijskom idejom su bile SAD. Međutim, posledice nametanja geopolitike neoosmanizma su da je Turska 2015/2016 bila pred građanskim ratom, a na spoljnom planu u sukobu sa svim zemljama u okruženju.

Erdogan i njegovi ključni savetnici, kao što je gradonačelnik Ankare Melih Gokček (Melih Gökçek) shvatali su da je Turska pred raspadom, i početkom 2016. odlučuju da promene politiku, da se vrate na umerenu evroazijsku geopolitiku. S tim u vezi u martu 2016. počinju pregovore sa Rusijom, a na unutrašnjem planu dozvoljavaju da političke ideje evroazijstva budu slobodno zastupljene (organizuju se tribine, naučni skupovi o evroazijskom identitetu i geopolitici u kojima posebno mesto zauzima obnavljač evroazijske ideje u Rusiji geopolitikolog Aleksandar Dugin). ${ }^{26}$

Prema tome, različito geopolitičko ponašanje savremene Turske je posledica njene geopolitičke raspolućenosti između evroazijskih ideja koje su oživele iz samog turskog društva, s jedne strane, i, s druge strane, geopolitičke prakse atlantizma u kome Turska učestvuje. Atlantizam je direktno uslovio period panturkizma devedesetih godina 20. veka i period neoosmanizma od 2011. do 2016. godine. Saradnja sa Rusijom od 2003. do 2007. godine, delimično do 2011, i ponovo od 2016. godine su posledica razvoja ideja geopolitičkog evroazijstva.

Turska je i dalje u sastavu NATO. U spoljnoj politici, ekonomiji ima jaku saradnju sa Rusijom. Postepeno se distancirala od Saudijske Arabije. U Siriji deluje zajedno sa Rusijom. Narednih godina, sveopšta kriza Zapada, jačanje Rusije, Kine, Irana biće spoljni faktori koji će uticati na geopolitiku Turske. Međutim, unutrašnji identitet Turske, njen

\footnotetext{
${ }^{25}$ Dobri odnosi su potvrđeni posetom Erdogana Srbiji u oktobru 2017. godine. U okviru posete predsednici Vučić i Erdogan su posetili i Novi Pazar, gde je Erdogan pozvao Bošnjake da poštuju državu Srbiju kao svoju državu. U toj poseti se vidi taj otklon od neoosmanizma, za vreme koga je Davutoglu isticao da je „Bosna Turska“, i Erdogan da je „Kosovo Turska“.

${ }^{26}$ Геополитиколог Александар Дугин је у Турској био и уочи и на сам дан државног удара, где је био гост градоначелника Анкаре. Он то објашњава у емисији „Попытка государственного переворота в Турции [Директива Дугина]“, Царьград TV, https://www.youtube.com/watch?v=MpLli1WeGR0 (pristupljeno: 21.9.2018).
} 
identitet kopna sve više dolazi do izražaja. „Geopolitički identitet nacije možemo odrediti kao spoj prostora na kome su se nacija i njena državnost izgrađivali, kulturno-civilizacijskog identiteta kome nacija/država pripada i uticaja dominantnog pogleda na svet." ${ }^{27} \mathrm{Ja}$ sno je da Turska nema atlantistički identitet, već upravo onaj koji je sučeljen Zapadu, evroazijski, kopneni. Na koji način će se ta dva identiteta sučeljavati u Turskoj gledaćemo narednih godina. U svakom slučaju, mala je verovatnoća da će se Erdogan vratiti na atlantističke koncepte neoosmanizma. Isto tako, potrebne su godine da se evroazijska ideja potpuno razvije u eliti Turske.

\section{Literatura}

[1] Bžežinski Zbignjev, Velika šahovska tabla, CID Podgorica, 1999.

[2] Bellaigue Christopher, „Turkey Goes Out of Control“, The New York Review of Books, 3. April 2014.

[3] Варткез Арцруни, „К истории советско-турецких отношений и дружбы большевиков с Ататюрком“, Ноевковчег, №10-11, июнь 2015, Москва. (стр. 262-273).

[4] Вести Турции Босфор: „Турция и Россия договорились о безвизовом режиме“, 17.3.2011. http://www.vestiturkey.com/turci-i-rossi-dogovorilis-o-bezvizovom-rezime-707h.htm

[5] Galijašević Dževad, „Neoosmanizam: Turska između juče i sutra“, Politea, br. 2/2011, Fakultet političkih nauka, Banjaluka.

[6] Gareth H. Jenkins, "The Changing Object of Fear: The Arrest of Ilker Basbug" (9 January 2012). https://www.turkeyanalyst.org/publications/turkey-analyst-articles/item/290-the-changing-objectsof-fear-the-arrest-of-ilker-basbug.html

[7] Daily Sabah, 23 April 2016, High-profile Gülen Movement-linked suspects remain fugitives; NTV, 20 July 2016, Ergenekon davası hakimi darbe soruşturmasında tutuklandı http://www.dailysabah.com/investigations/2016/04/23/high-profile-gulen-movement-linkedsuspects-remain-fugitives;

[8] Davutoglu Ahmet, Strategija dubine: međunarodni položaj Turske, Službeni glasnik, Beograd, 2014.

[9] Дугин Александар, „Неоосманская иллюзия Турции“, Нешсланд, Москва, 25.01.2013, https://newsland.com/user/4297700690/content/aleksandr-dugin-neoosmanskaia-illiuziia-turtsii/4438003

[10] Dugin Aleksandar, „Tursku sa neoosmanizmom čekaju haos, neredi i raspad države“, Nova srpska politička misao, Beograd, februar 2013, http://www.nspm.rs/hronika/aleksandardugin-tursku-sa-neo-osmanizmom-cekaju-haos-neredi-i-raspad-drzave.html?alphabet=l

[11] Дугин Александар, „Попытка государственного переворота в Турции [Директива Дугина]“, Царьград ТВ, 2016, https://www.youtube.com/watch?v=MpLli1WeGR0

[12] Đurković Miša, "Fetulah Gjulen i džemat Hizmet", Polja geopolitike - zbornik radova (prir. Ljubiša Despotović, Veselin Konatar), Kultura - polis i Fakultet za evropske i pravno političke studije, 2016.

\footnotetext{
${ }^{27}$ Srđan Perišić, „Srbija i geopolitika: od identiteta ka praktičnoj geopolitici i strategiji“, Zbornik radova sa Naučnog skupa „Srbija i strategijska raskršća - ISIKS 2016“, Institut za strategijska istraživanja MO R.Srbije, Škola nacionalne odbrane - Univerzitet odbrane, Beograd, 2016
} 
[13] Jakšić Boško, „Nepoznati detalji neuspešnog državnog udara u Turskoj - Kako je poziv iz Moskve spasao Erdogana“, Politika, 20.09.2016, http://www.politika.rs/scc/clanak/363954/Kako-jepoziv-iz-Moskve-spasao-Erdogana

[14] Kuzmanović B, Kovač M, „Implikacije kurdskog nacionalnog pitanja na situaciju u Turskoj“, Vojno delo, 2/2018, Beograd, str. 113 - 134.

[15] Мейгун Елена, „Власти тюркских регионов выбирают между Россией и Турцией“, Национальный акцент, Москва, 27.12.2015,

http://nazaccent.ru/content/18885-svoj-ili-tyurksoj.html

[16] Папава Василий, „Интервью с М. Перинчеком“, Ежемесячный общественно-политический журнал Кавказский Акцент. № 12 за декабрь 2010.

[17] Peltier Isaac J., Surrogate Warfare: The Role of U.S. Army Special Forces, School of Advanced Military Studies United States Army Command and General Staff College Fort Leavenworth, Kansas, 2004/2005, p. 24-30.

[18] Perišić Srđan, Nova geopolitika Rusije, Medija centar Odbrana, Beograd, 2015.

[19] Perišić Srđan, „Srbija i geopolitika: od identiteta ka praktičnoj geopolitici i strategiji“, Zbornik radova Srbija i strategijska raskršća - ISIKS 2016, Institut za strategijska istraživanja MO R. Srbije, Škola nacionalne odbrane - Univerzitet odbrane, Beograd, 2016.

[20] Sakan Momčilo, „Geopolitika Republike Turske“, Vojno delo, 1/2015, Beograd.

[21] Tanasković Darko, Neoosmanizam: povratak Turske na Balkan, JP Službeni glasnik, Beograd, 2010.

[22] Hurriyet Daily News: "Former army chief's jailing a rights violation: Top Turkish court". Hürriyet Daily News. 6 March 2014.

[23] Шлыков Павел, „Анкара смеется последней - Как Советская Россия помогла становлению независимой Турции“, Лента, Москва, април 2016. 